\title{
Meningkatkan Mutu Pendidikan Melalui Metode E-Learning
}

\author{
Irjus Indrawan, S.Pd.I.. M.Pd.I \\ Dosen Fakultas Ilmu Agama Islam Universitas Islam Indragiri \\ (UNISI) Tembilahan Kabupaten Indragiri Hilir
}

\begin{abstract}
Abstrak
E-learning merupakan suatu model pembelajaran yang dibuat dalamformat digital melalui perangkat elektronik. Tujuan digunakannya E-learningdalam sistem pembelajaran adalah untuk memperluas akses pendidikan kemasyarakat luas.E-learning semakin dikenal sebagai salah satu cara untuk mengatasi masalah pendidikan, baik di negaranegara maju maupun di negara yangsedang berkembang. E-learning merupakan suatu teknologi pembelajaran yang yang relatif barudi Indonesia.E-learningadalah pembelajaran dengan menggunakan jasa bantuan perangkatelektronika. Jadi dalam pelaksanaannya E-learning menggunakan jasa audio,video atau perangkat komputer atau kombinasi dari ketiganya. Banyak hal yang mendorong mengapa E-learning menjadi salah satu pilihanuntuk peningkatan mutu pendidikan, antara lain pesatnya fasilitas teknologiinformasi, dan perkembangan

pengguna internet di dunia saat ini berkembangdengan cepat.
\end{abstract}

Keyword: Mutu pendidikan, Metode, E-learning

\section{A. Pendahuluan}

E-learning merupakan suatu model pembelajaran yang dibuat dalam format digital melalui perangkat elektronik. Tujuan digunakannya E-learning dalam sistem pembelajaran adalah untuk memperluas akses pendidikan kemasyarakat luas. Ilmu dan teknologi informasi berkembang sangat pesat yang berdampak pada perubahan sosial budaya. Seperti e-commerce satu perubahan radikal dalam aspek ekonomi masyarakat modern. Sektor pemerintahan terjadinya e-government dan di sektor pendidikan disebut E-learning. Di Indonesia pemanfaatan teknologi internet dimulai sekitar tahun 1995 ketika Indo Internet membuka jasa layanan internet dan tahun 1997-an mulai berkembang pesat. Namun pemanfaatan teknologi ini masih didominasi oleh lembaga seperti perbankan, perdagangan, media massa, atau kalangan industri. Pemanfatan teknologi internet untuk pendidikan di Indonesia secara resmi dimulai sejak diben- 
tuknya telematika tahun 1996.

Seiring perkembangan zaman dan perkembangan ilmu pengetahuan, pemanfaatan internet untuk pendidikan ini tidak hanya untuk pendidikan jarak jauh, akan tetapi juga dikembangkan dalam sistem pendidikan konvensional. ${ }^{1}$ Kini sudah banyak lembaga pendidikan terutama perguruan tinggi yang sudah mulai merintis dan mengembangkan model pembelajaran berbasis internet dalam mendukung sistem pendidikan konvensional. Internet sebagai media baru belum memasyarakat, demikian pula orang-orang yang terlibat dalam lembaga pendidikan belum terbiasa menggunakan media internet ini.

Dalam penyelenggaraan pendidikan nasional yang bersifat konvensional, mengalami banyak kendala ketika dituntut untuk memberikan pelayanannya bagi masyarakat luas yang tersebar di seluruh Nusantara. Kendala tersebut diantaranya adalah keterbatasan finansial, jauhnya lokasi, dan keterbatasan jumlah institusi. Saat ini telah berkembang teknologi informasi yang dapat dimanfaatan untuk mengatasi kendala tersebut. Sudah saatnya teknologi informasi dimanfaatkan secara optimal dalam penyelenggaraan pendidikan di Indonesia.Terlebih di masa depan pendidikan akan mengahadapi persaingan global yang sangat ketat. Agar dapat memenangkan ataupun dapat ikut bermain dalam dinamika global membutuhkan prasyarat kekuatan kepercayaan diri dan kemandirian.

\section{B. Pembahasan}

\section{E-Learning}

Pergeseran peraturan dalam sistem pendidikan yang semula sentralisasi menjadi desentralistis membawa perubahan dalam sistem pengelolaan pendidikan, khususnya di tingkat sekolah. Kebijakan tersebut dapat dimaknai sebagai pemberian otonomi yang seluas-luasnya kepada sekolah dalam mengelola sekolah untuk berinovasi dalam pengembangan kurikulum dan menerapkan model-model dalam pembelajaran. Ini be-

1 Lihat kamus popular ilmiah lengkap, Pendidikan yang bersifat Konvensional maksudnya adalah pelaksanaannya dilaksanakan berdasarkan kondisi dan tatacara, menurut atau secara adat kebiasaan, secara persepakatan/persetujuan yang ada. 
rarti bahwa pendidikan adalah termasuk yang diotonomikan dimana pemerintah pusat harus bersedia dikurangi kekuasaan dan perannya serta bersedia menyerahkan tanggung jawab pembinaan pendidikan kepada pemerintah daerah, sekolah/ madrasah dan masyarakat setempat untuk mengatur sekolah/ madrasahnya sendiri. ${ }^{2}$

Otonomi yang luas itu, hendaknya diimbangi dengan perubahan yang berorientasi kepada kinerja dan partisipasi secara menyeluruh dari komponen pendidikan yang terkait. Konsekuensi yang harus ditanggung oleh sekolah adalah restrukturisasi dalam pengelolaan sekolah (capacity building), profesionalisme guru, penyiapan infrastruktur, kesiapan siswa dalam proses belajar dan iklim akademik sekolah. Peningkatan kemampuan manajemen pendidikan merupakan persyaratan yang tidak dapat dihindari. ${ }^{3}$

Kebijakan otonomi pendidikan juga diharapkan melahirkan organisasi sekolah yang sehat serta terciptanya daya saing sekolah. Sejalan dengan perkembangan teknologi informasi dan pembelajaran berbasis teknologi informasi yang sangat pesat, hendaknya sekolah menyikapinya dengan seksama agar apa yang dicita-citakan dalam perubahan paradigma pendidikan dapat segera terwujud. Kecenderungan yang telah dikembangkan dalam pemanfaatan teknologi informasi dan komunikasi (TIK) dalam pembelajaran adalah program E-learning. Secara sederhana E-learning dapat difahami sebagai suatu proses pembelajaran yang memanfaatkan teknologi informasi berupa komputer yang dilengkapi dengan sarana telekomunikasi (internet) dan multimedia (grafis, audio, video), sebagai media utama dalam penyampaian materi dan interaksi antara pengajar (guru/dosen) dan pembelajar (siswa/mahasiswa) dengan menggunakan media dalam pengajaran dapat mempertinggi hasil belajar siswa yang dicapai. ${ }^{4}$

2 Samsul Nizar, M. Syaifudin. Isu-Isu Kontemporer Tentang Pendidikan Islam. Jakarta: Kalam Mulia, 2010, hal. 45

3 Yusufhadi Miarso. Menyemai Benih Teknologi Pendidikan. Jakarta: Kencana, 2007, hal. 726

4 Nana Sudjana, Ahmad Rivai. Media Pengajaran.Bandung: Sinar Baru Algensin- 
E-learning semakin dikenal sebagai salah satu cara untuk mengatasi masalah pendidikan, baik di negara-negara maju maupun di negara yangsedang berkembang. E-learning merupakan suatu teknologi pembelajaran yang yang relatif barudi Indonesia. Kata E-learning ini terdiri dari dua bagian, yaitu 'e' yang merupakan singkatan dari 'electronica' dan 'learning' yang berarti 'pembelajaran'. Jadi E-learning berarti pembelajaran dengan menggunakan jasa bantuan perangkat elektronika. Jadi dalam pelaksanaannya E-learning menggunakan jasa audio, video atau perangkat komputer atau kombinasi dari ketiganya.

Banyak hal yang mendorong mengapa E-learning menjadi salah satu pilihan untuk peningkatan mutu pendidikan, antara lain pesatnya fasilitas teknologi informasi, dan perkembangan pengguna internet di dunia saat ini berkembang dengan cepat. Penggunaan internet menjadi suatu kebutuhan dalam mendukung pekerjaan atau tugas sehari-hari. Apalagi dengan tersedianya fasilitas jaringan (internet infrastructure) dan koneksi internet (internet connections). Serta tersedianya piranti lunak pembelajaran (management course tools). Juga orang yang terampil mengoperasikan atau menggunakan internet semakin meningkat jumlahnya. ${ }^{5}$

Penemuan internet dianggap sebagai penemuan yang cukup besar, yang mengubah dunia dari bersifat lokal atau regional menjadi global. Sumber informasi dunia dapat diakses oleh siapa pun dan di mana pun melalui jaringan internet. Melalui internet faktor jarak dan waktu sudah tidak menjadi masalah. Dunia seolah-olah menjadi kecil, dan komunikasi menjadi mudah, internet juga telah mengubah metode komunikasi massa dan penyebaran data atau informasi secara fleksibel dan mengintegrasikan seluruh bentuk media massa konvensional seperti media cetak dan audio visual.

do, 2005, hal. 2

5 Soekartawi. Prospek Pembelajaran Melalui Internet. Makalah disampaikan pada Seminar Nasional 'Teknologi Kependidikan' yang diselenggarakan oleh UTPustekkom dan IPTPI, Jakarta, 18-19 Juli 2002 
2. Meningkatkan Mutu Pendidikan Melalui E-learning

Media seperti radio, televisi, video, multi media, dan media lainnya telah digunakan dan dapat membantu meningkatkan mutu pendidikan. E-learning dapat mengacu pada semua kegiatan pelatihan yang menggunakan media elektronik atau teknologi informasi sebagai media kegiatan pendidikan. ${ }^{6}$ Apalagi media internet yang memiliki sifat interaktif, bisa sebagai media massa dan interpersonal, gudangnya sumber informasi dari berbagai penjuru dunia, sangat dimungkinkan menjadi media pendidikan lebih unggul dari generasi sebelumnya. Dengan fasilitas yang dimilikinya. Paling tidak ada tiga hal dampak positif penggunaan internet dalam pendidikan yaitu : a. Peserta didik dapat dengan mudah mengambil mata kuliah di manapun di seluruh dunia tanpa batas institusi atau batas negara.

b. Peserta didik dapat dengan mudah berguru pada para ahli di bidang yang diminatinya.

c. Kuliah/belajar dapat dengan mudah diambil di berbagai penjuru dunia tanpa bergantung pada universitas/sekolah tempat si mahasiswa belajar.

Di samping itu kini hadir perpustakan internet yang lebih dinamis dan bisa digunakan di seluruh jagat raya. Manfaat internet bagi pendidikan adalah dapat menjadi akses kepada sumber informasi, akses kepada nara sumber, dan sebagai media kerjasama. Akses kepada sumber informasi yaitu sebagai perpustakaan online, sumber literatur, akses hasil-hasil penelitian, dan akses kepada materi kuliah. Akses kepada nara sumber bisa dilakukan komunikasi tanpa harus bertemu secara fisik. Sedangkan sebagai media internet bisa menjadi media untuk melakukan penelitian bersama atau membuat semacam makalah bersama.

Mengingat topografi dan demografi penduduk Indonesia yang kurang menguntungkan, maka kita sudah saatnya memikirkan sistem pendidikan yang dapat dijangkau oleh penduduk paling terpencil dan paling minim sumberdayanya.

6 Empy Effendi. Hartono Zhuang. E-Learning, Konsep dan Aplikasi. Yogyakarta. Andi: 2005, hal. 4 
Dilihat dari upaya penerapan teknologi tersebut, sungguh banyak potensi yang dapat dijadikan modal dasar penerapan teknologi informasi dalam pendidikan masyarakat. Ada beberapa alasan yang dapat diangkat, bahwa teknologi informasi dapat diterapkan dalam media pendidikan, di antaranya:

1. Banyak sekolah yang memiliki komputer sendiri sehingga dimungkinkan untuk dikembangkan paket belajar Personal-Interaktif yang materi ajarnya dikemas dalam suatu software. Peserta dapat belajar dengan cara menjalankan program komputer atau perangkat lunak tersebut di computersecara mandiri dan di lokasi masing-masing. Melalui paket program belajar ini peserta dapat melakukan simulasi atau juga umpan balik tentang kemajuan belajarnya.

2. Negara Indonesia terdiri atas ribuan pulau yang tersebar dalam wilayah yang sangat luas, serta dihuni lebih dari 200 juta penduduk dengan distribusi secara tidak homogen. Kondisi ini memang disadari memiliki kendala ketika akan diterapkan sistem pendidikan konvensional (tatap muka). Maka teknologi informasi yang mungkin diterapkan untuk kondisi tersebut adalah melalui jaringan internet. Melalui media ini proses belajar dapat dijalankan secara on line atau di-down-load untuk keperluan off line. Peserta didik dapat mengakses sistem kapan saja dan sesering mungkin, tidak terbatas pada jam belajar dan tidak tergantung pada tempat.

3. Untuk kesamaan mutu dalam memperolah materi, dikembangkan paket belajar terdistribusi yaitu materi belajar ditempatkan/disimpan di sebuah server yang tersambung ke internet sehingga dapat diambil oleh peserta ajar baik memakai Web-Browser ataupun File Transport Protocol (aplikasi pengiriman file).

Internet sebagai media pendidikan memiliki keunggulan, dan kelemahan. Namun infrastruktur internet masih terbatas dan tergolong pada peralatan yang mahal. Keterbatasan dana, dan budaya baca kita masih lemah. Di sinilah tantangan bagaimana mengembangkan model pembelajaran melalui internet. 


\section{$74 \frac{\text { Jurnal AL-AFKAR }}{\text { Vol. III, No. II, Oktober } 2014}$}

3. Metode Pembelajaran

Pada dasarnya cara penyampaian atau cara pemberian (delivery system) dari E-learning, dapat digolongkan menjadi dua, yaitu: komunikasi satu arah dan komunikasi dua arah. Komunikasi atau interaksi antara guru dan murid memang sebaiknya melalui sistem dua arah. Dalam E-learning, sistem dua arah ini juga bisa diklasifikasikan menjadi dua, yaitu:

a. Dilaksanakan melalui cara langsung artinya pada saat instruktur memberikan pelajaran, murid dapat langsung mendengarkan.

b. Dilaksanakan melalui cara tidak langsung misalnya pesan dari instruktur direkam dahulu sebelum digunakan.

Karakteristik E-learning ini antara lain adalah:

a. Memanfaatkan jasa teknologi elektronik. Guru dan siswa, siswa dan sesama siswa atau guru dan sesama guru dapat berkomunikasi dengan relatif mudah tanpa dibatasi oleh hal-hal yang bersifat protokoler.

b. Memanfaatkan keunggulan komputer (digital media dan computer networks)

c. Menggunakan bahan ajar bersifat mandiri (self learning materials) disimpan di komputer sehingga dapat diakses oleh guru dan siswa kapan saja dan di mana saja bila yang bersangkutan memerlukannya.

d. Memanfaatkan jadwal pembelajaran, kurikulum, hasil kemajuan belajar dan hal-hal yang berkaitan dengan administrasi pendidikan dapat dilihat setiap saat di komputer. ${ }^{?}$

Pemanfaatan E-learning tidak terlepas dari jasa internet. Karena teknik pembelajaran yang tersedia di internet begitu lengkap, maka hal ini akan mempengaruhi tugas guru dalam proses pembelajaran. Dahulu, proses belajar mengajar didominasi oleh peran guru, karena itu disebut the era of teacher. Kini, proses belajar dan mengajar, banyak didominasi oleh peran guru dan buku (the era of teacher and book) dan pada masa mendatang proses belajar dan mengajar akan didominasi oleh

7 Dewi Salma Prawiradilaga, Evelina Siregar. Mozaik Teknologi Pendidikan. Jakarta: Kencana, 2007, hal. 199 
peran guru, buku dan teknologi (the era of teacher, book and technology). Dalam era global seperti sekarang ini, setuju atau tidak, mau atau tidak mau, kita harus berhubungan dengan teknologi khususnya teknologi informasi. Hal ini disebabkan karena teknologi tersebut telah mempengaruhi kehidupan kita sehari-hari. Oleh karena itu, kita sebaiknya tidak 'gagap' teknologi. Banyak hasil penelitian menunjukkan bahwa siapa yang terlambat menguasai informasi, maka terlambat pulalah memperoleh kesempatan untuk maju.

Peran informasi menjadi kian besar dan nyata dalam dunia modern sekarang ini. Hal ini bisa dimengerti karena masyarakat sekarang menuju pada era masyarakat informasi (information age) atau masyarakat ilmu pengetahuan (knowledge society). Oleh karena itu tidak mengherankan kalau ada perguruan tinggi yang menawarkan jurusan informasi atau teknologi informasi, maka perguruan tinggi tersebut berkembang menjadi pesat. Perkembangan pengguna internet di dunia ini berkembang sangat cepat karena beberapa hal, antara lain:

a. Menggunakan internet adalah suatu kebutuhan untuk mendukung pekerjaan atau tugas sehari-hari

b Tersedianya fasilitas jaringan (internet infrastructure) dan koneksi internet (internet connections)

c. Semakin tersedianya piranti lunak pembelajaran (management course tools)

d. Keterampilan jumlah orang yang mengoperasikan atau menggunakan internet

e. Kebijakan yang mendukung pelaksanaan program yang menggunakan internet tersebut. ${ }^{8}$

Pengembangan E-learning tidak semata-mata hanya menyajikan materi pelajaran secara on-line saja, namun harus komunikatif dan menarik. Materi pelajaran didesain seolah peserta didik belajar di hadapan pengajar melalui layar komputer yang dihubungkan melalui jaringan internet. Untuk dapat menghasilkan E-learning yang menarik dan diminati,

8 Soekartawi. Prospek Pembelajaran Melalui Internet. Makalah disampaikan pada Seminar Nasional 'Teknologi Kependidikan' yang diselenggarakan oleh UTPustekkom dan IPTPI, Jakarta, 18-19 Juli 2002 
ada tiga hal yang wajib dipenuhi dalam merancang E-learning, yaitu "sederhana, personal, dan cepat". Sistem yang sederhana akan memudahkan peserta didik dalam memanfaatkan teknologi dan menu yang ada , dengan kemudahan pada panel yang disediakan, akan mengurangi pengenalan systemE-learning itu sendiri, sehingga waktu belajar peserta dapat diefisienkan untuk proses belajar itu sendiri dan bukan pada belajar menggunakan sistem elearning-nya.

Syarat personal berarti pengajar dapat berinteraksi dengan baik seperti layaknya seorang guru yang berkomunikasi dengan murid di depan kelas. Dengan pendekatan dan interaksi yang lebih personal, peserta didik diperhatikan kemajuannya, serta dibantu segala persoalan yang dihadapinya. Hal ini akan membuat peserta didik betah berlama-lama di depan layar komputernya. Kemudian layanan ini ditunjang dengan kecepatan, respon yang cepat terhadap keluhan dan kebutuhan peserta didik lainnya. Dengan demikian perbaikan pembelajaran dapat dilakukan secepat mungkin oleh pengajar atau pengelola.

4. Faktor-Faktor dalam Pemanfaatan E-learning

Ahli-ahli pendidikan dan ahli internet menyarankan beberapa hal yang perlu diperhatikan sebelum seseorang memilih internet untuk kegiatan pembelajaran antara lain:

a. Analisis Kebutuhan (Need Analysis)

Dalam tahapan awal, satu hal yang perlu dipertimbangkan adalah apakah memang memerlukan E-learning. Pertanyaan ini tidak dapat dijawab dengan perkiraan atau dijawab berdasarkan atas saran orang lain. Setiap lembaga menentukan teknologi pembelajaran sendiri yang berbeda satu sama lain. Untuk itu perlu diadakanan alisis kebutuhan atau need analysis yang mencakup studi kelayakan baik secara teknis, ekonomis, maupun sosial.

b. Rancangan Instruksional yang berisi tentang isi pelajaran, topik, satuan kredit, bahan ajar/kurikulum.

c. Evaluasi yaitu sebelum program dimulai, ada baiknya dicobakan dengan mengambil beberapa sampel orang yang dimintai tolong untuk ikut mengevaluasi. 
Terakhir yang harus diperhatikan masalah yang sering dihadapi yaitu:

a. Masalah akses untuk bisa melaksanakan E-learning seperti ketersediaan jaringan internet, listrik, telepon dan infrastruktur yang lain.

b. Masalah ketersediaan software (piranti lunak). Bagaimana mengusahakan piranti lunak yang tidak mahal.

c. Masalah dampaknya terhadap kurikulum yang ada.

d. Masalah skill. ${ }^{9}$

Oleh karena itu perlu diciptakan bagaimana semuanya mempunyai sikap yang positif terhadap media internet dan perangkatnya sehingga penggunaan teknologi baru bisa mempercepat pembangunan.

5. Kelebihan dan Kekurangan E-learning

Menyadari bahwa di internet dapat ditemukan berbagai informasi dan informasi itu dapat diakses secara lebih mudah, kapan saja dan di mana saja, maka pemanfaatan internet menjadi suatu kebutuhan. Bukan itu saja, pengguna internet bisa berkomunikasi dengan pihak lain dengan cara yang sangat mudah melalui teknik e-moderating yang tersedia di internet. Contoh SMART School di Malaysia. Ada empat hal yang perlu disiapkan sebelum pemanfaatan internet untuk E-learning yaitu:

a. Melakukan penyesuaian kurikulum. Kurikulum sifatnya holistik. Pengetahuan, keterampilan dan nilai (values) diintegrasikan dengan kebutuhan di era informasi ini. Kurikulumnya bersifat competency based curriculum.

b. Melakukan variasi cara mengajar untuk mencapai dasar kompetensi yang ingin dicapai dengan bantuan komputer.

c. Melakukan penilaian dengan memanfaatkan teknologi yang ada (menggunakan komputer, online assessment system)

d. Menyediakan material pembelajaran seperti buku, komputer, multimedia, studio, dll yang memadai. Materi pembelajaran yang disimpan di computerdapat diakses dengan mudah baik oleh guru maupun siswa.

9 Dewi Salma Prawiradilaga, Evelina Siregar. Op. Cit Hal. 210 
Dari berbagai pengalaman dan juga dari berbagai informasi yang tersedia di literatur, memberikan penjelasan tentang manfaat penggunaan internet, khususnya dalam pendidikan terbuka dan jarak jauh, antaralain dapat disebutkan sebagai berikut:

a. Tersedianya fasilitas e-moderating dimana guru dan siswa dapat berkomunikasi secara mudah melalui fasilitas internet secara regular atau kapan saja kegiatan berkomunikasi itu dilakukan tanpa dibatasi oleh jarak,tempat dan waktu.

b. Guru dan siswa dapat menggunakan bahan ajar atau petunjuk belajar yang terstruktur dan terjadwal melalui internet, sehingga keduanya bisa saling menilai sampai berapa jauh bahan ajar dipelajari.

c. Siswa dapat belajar atau me-review bahan ajar setiap saat dan di manasaja kalau diperlukan mengingat bahan ajar tersimpan di komputer.

d. Bila siswa memerlukan tambahan informasi berkaitan dengan bahan yangdipelajarinya, ia dapat melakukan akses di internet secara lebih mudah.

e. Baik guru maupun siswa dapat melakukan diskusi melalui internet yang dapat diikuti dengan jumlah peserta yang banyak, sehingga menambah ilmu pengetahuan dan wawasan yang lebih luas.

f. Berubahnya peran siswa dari yang biasanya pasif menjadi aktif

g. Relatif lebih efisien. Misalnya bagi mereka yang tinggal jauh dari perguruan tinggi atau sekolah konvensional, bagi mereka yang sibuk bekerja, bagi mereka yang bertugas di kapal, di luar negeri, dan sebagainya.

Walaupun demikian, pemanfaatan internet untuk pembelajaran atau E-learning juga tidak terlepas dari berbagai kekurangan antara lain:

a. Kurangnya interaksi antara guru dan siswa atau bahkan antar siswa itu sendiri. Kurangnya interaksi ini bisa memperlambat terbentuknya value dalam proses belajar dan mengajar.

b. Kecenderungan mengabaikan aspek akademik atau aspek 
sosial dan sebaliknya mendorong tumbuhnya aspek bisnis

c. Proses belajar dan mengajarnya cenderung ke arah pelatihan bukan pendidikan.

d. Berubahnya peran guru dari yang semula menguasai teknik pembelajaran konvensional, kini juga dituntut menguasai teknik pembelajaran yangmenggunakan internet.

e. Siswa yang tidak mempunyai motivasi belajar tinggi cenderung gagal.

f. Tidak semua tempat tersedia fasilitas internet (mungkin hal ini berkaitan dengan masalah tersedianya listrik, telepon ataupun komputer).

g. Kurangnya tenaga yang mengetahui dan memiliki keterampilan bidanginternet dan kurangnya penguasaan bahasa komputer. ${ }^{10}$

Saat ini pemerintah telah berupaya untuk memanfaatkan dan memaksimalkan tersedianya informasi teknologi dengan membentuk Kantor Menteri Negara Informasi dan Teknologi. Di tiap departemen bahkan ada unit yang menangani teknologi informasi. Di Depdiknas misalnya ada Pustekkom atau Pusat Teknologi Komunikasi dan Informasi untuk Pendidikan; di tiap Universitas ada Pusat Komputer, dan masih banyak contoh lain. E-learning kini banyak digunakan oleh para penyelenggara pendidikan terbuka dan jarak jauh. Kalau dahulu hanya Universitas Terbuka yang diijinkan menyelenggarakan pendidikan jarak jauh, maka kini dengan terbitnya Surat Keputusan Menteri Pendidikan Nasional No.107/U/2001 (2 Juli 2001) tentang 'Penyelenggaraan Program Pendidikan Tinggi Jarak Jauh', maka perguruan tinggi tertentu yang mempunyai kapasitas menyelenggarakan pendidikan terbuka dan jarak jauh menggunakan E-learning, juga telah diizinkan untuk menyelenggarakannya.

Lembaga-lembaga pendidikan non-formal seperti kursuskursus, juga telah memafaatkan keunggulan E-learning ini untuk program-programnya. Melalui pemanfaatkan teknologi informasi, diharapkan materi ajar dapat diakses oleh siapa saja

10 Dewi Salma Prawiradilaga, Evelina Siregar. Op. Cit Hal. 202 
dan kapan saja. Akses terhadap materi ajar sebenarnya dapat diatur bila dikehendaki karena tersedia fasilitas pengaman. Hanya orang yang telah mendaftar saja yang bisa mengakses materi ajar tersebut. Karena mahalnya pembuatan bahan ajar maka negara sebagai penanggung jawab mencerdaskan kehidupan bangsa perlu menyiapkan bahan tersebut sehingga dapat dipakai di seluruh Indonesia. Persoalan mendasar berkenaan dengan model ajar ini, adalah keterbatasan pihak sekolah untuk menyediakan komputer termasuk internet dalam proses pengajaran. Oleh karena itu perlu ada aksi untuk menyiapkan institusi pendidikan (ready for learning), yaitu dengan cara melibatkan para guru dan departemen terkait, misalnya depdiknas, dan departemen ristek yang ada di wilayah masing-masing. Mereka ini harus menyiapkan termasuk mengetahui materi ajar yang tersedia dan cara akses atau mendapatkannya. Mereka bertanggung jawab membantu institusi pendidikan termasuk mengkomunikasikan materi ajar yang tidak dipahami sehingga dapat mempelajarinya dalam waktu tertentu.

Saat ini telah banyak sekali sumber belajar yang berbasis komputer bahkan berbasis multmedia (buatan dalam dan luar negeri) baik yang berfungsi sebagaimateri pokok, maupun sebagai materi pengayaan. Namun penelitian tentang dampak dari penggunaan sumber belajar tersebut belum banyak dilakukan, terutama dalam hal kemungkinan adanya miskonsepsi yang ditimbulkan oleh sumber belajar itu. Oleh karena itu, studi tentang pengembangan, uji coba dan standardisasi perangkat lunak komputer kependidikan harus segera dilakukan oleh departemen atau pihak yang berkepentingan dan kita semua.

6. Cara Melaksanakan E-learning

Dengan adanya perkembangan yang sangat pesat dalam teknologi, konsep E-learning akan lebih mudah untuk dilaksanakan. E-learning dapat dilaksanakan dan sangat akan mempermudah dalam proses pembelajaran, ini tentunya jika adanya sarana pendukung pelaksanaan E-learning ini. Sistem E-learning merupakan perpaduan beberapa komponen yang masing-masingnya dapat berdiri sendiri, yaitu: 
a. Conten Delivery, yaitu bagian dari sistem yang menjadi perantara penyampaian isi dari materi pelajaran kepada pemakai. Dalam pengembangan conten delivery ini ada hal-hal yang harus diperhatikan, yaitu:

1) Konsistensi format tampilan dalam setiap aspek pembelajaran. Hal ini untuk menjaga agar para siswa fokus pada materi pelajaran, tanpa harus beradaptasi pada lingkungan yang selalu berubah.

2) Navigasi pada tampilan harus mudah dilihat dan bersifat mengarahkan pembelajar untuk mengikuti materi secara berurutan serta membatu siswa mencari hal yang ingin diketahui dengan cepat tanpa harus meninggalkan materi utamanya.

3) Jangan sampai menutup materi pelajaran yang sedang dipelajari, ini berguna untuk memudahkan siswa kembali pada halaman terakhir yang dipelajarinya.

4) Menuntun siswa agar tidak terjebak dalam kebosanan.

5) Pre-test simulation, dalam rangka mempersiapkan siswa untuk mengikuti ujian kuantitatif terhadap materi pelajaran yang dihadapi.

b. Resourse Management and Mentoring Support

Merupakan sistem pengelolaan infrastruktur dari sisi penyelenggara proses pembelajaran dengan tujuan mencapai tingkat ketersediaan yang maksimum. Bagian ini tidak langsung berhadapan dengan siswa tetapi merupakan media yang secara transparan digunakan dalam seluruh proses terkait dalam sistem E-learning.

c. Learning Management System

a. Regestration

Ini merupagan gerbang siswa untuk terlibat dalam E-learning terpadu. Ini merupakan reperentasi dari proses registrasi siswa baru dalam satu institusi pendidikan

b. Curriculum

Referensi dari silabus materi pengajaran yang dikembangkan setelah melalui satu proses uji coba, untuk selanjutnya ditampilkan pada antar muka siswa 


\section{2 \\ Jurnal AL-AFKAR \\ $\overline{\text { Vol. III, No. II, Oktober } 2014}$}

sesuai dengan tingkatan siswa pada saat ia mengakses sistem.

c. Competency management

Ini merupakan serangkaian pelatihan yang bersifat mengarahkan jenjang pendidikan seseorang.

d. Evalution

Adalah salah satu bagian proses penilaian untuk menentukan kelayakan siswa mencapai tingkatan tertentu berdasarkan peningkatan kompetensi yang dilaluinya. Ukuran keberhasilan pembelajaran e-leraning terpadu lebih pada penilaian kuantitatif siswa. ${ }^{11}$

\section{Kesimpulan}

E-learning adalah pembelajaran yang memerlukan alat bantu elektronika, dapat berupa audio dan video atau dengan bantuan perangkat komputer dan internet. Penggunaan teknologi E-learning sebenarnya dapat digunakan untuk pendidikan tatap muka, jarak jauh terggantung dari kepentingannya.

E-learning akan dimanfaatkan atau tidak sangat tergantung bagaimana pengguna memandang atau menilai E-learning tersebut. Namun umumnya digunakannya teknologi tersebut tergantung dari:

1. Apakah teknologi itu memang sudah merupakan kebutuhan

2. Apakah fasilitas pendukungnya memadai

3. Apakah didukung oleh dana yang memadai

4. Apakah ada dukungan dari pembuat kebijakan.

Kebijakan institusi pendidikan dalam memanfaatkan teknologi internet menuju E-learning perlu kajian dan rancangan mendalam. E-learning bukan semata-mata hanya memindahkan semua pembelajaran pada internet. Hakikat meningkatkan mutu pendidikan melalui E-learning adalah proses pembelajaran yang dituangkan melalui teknologi internet. Di samping itu prinsip sederhana, personal, dan cepat perlu dipertimbangkan. Di sini perlunya pengembangan model E-learning yang tepat sesuai dengan kebutuhan. Ada pendapat yang mengatakan bahwa media pembelajaran secanggih apapun ti-

11 Majalah Trend Teknologi Informasi. Jakarta. PT. Galva Tecnologies Corporation. 2001, Hal. 155 
dak akan bisa menggantikan sepenuhnya peran guru/dosen. Penanaman nila-nilai dan sentuhan kepribadian sulit dilakukan. Di sini tantangan bagi para pengambil kebijakan dan perancang E-learning. Oleh karena itu penulis sependapat bahwa dalam sistem pendidikan konvensional, fungsi E-learningadalah untuk memperkaya wawasan dan pemahaman peserta didik,serta proses pembiasaan agar peserta dididik melek terhadap sumber belajar khususnya teknologi internet.

\section{Daftar Pustaka}

Dewi Salma Prawiradilaga, Evelina Siregar. Mozaik Teknologi Pendidikan. Jakarta: Kencana, 2007

Empy Effendi. Hartono Zhuang. E-learning, Konsep dan Aplikasi. Yogyakarta. Andi: 2005

Majalah Trend Teknologi Informasi. Jakarta. PT. Galva Tecnologies Corporation. 2001

Nana Sudjana, Ahmad Rivai. Media Pengajaran. Bandung: Sinar Baru Algensindo, 2005

Susilo Riyawadi, Suci Nur Anisyah. Kamus Popular Ilmiah Lengkap. Surabaya: Sinar Terang

Samsul Nizar, M. Syaifudin. Isu-Isu Kontemporer Tentang Pendidikan Islam. Jakarta: Kalam Mulia, 2010

Soekartawi. Prospek Pembelajaran Melalui Internet. Makalahdisampaikan pada Seminar Nasional 'Teknologi Kependidikan' yang diselenggarakan oleh UT-Pustekkom dan IPTPI, Jakarta, 18-19 Juli 2002

Yusufhadi Miarso. Menyemai Benih Teknologi Pendidikan. Jakarta: Kencana, 2007 